\title{
Seeing like a scientist: subjunctive forensics and shared ways of seeing in the Spanish forensic archive
}

\author{
Ver como una experta: ciencias forenses subjuntivas y modos \\ compartidos de ver en el archivo forense español \\ Aditu baten begirada: zientzia forentse subjuntiboak eta ikuspegi \\ partekatuak Espainiako artxibo forentsean
}

\author{
Lee Douglas \\ Universidade Nova de Lisboa \\ Idouglas@fcsh.unl.pt \\ https://orcid.org/0000-0002-3916-8527
}

\begin{abstract}
For two decades, Spaniards have turned to forensic science as a mode of unearthing diverse forms of evidence that shed light on the mechanics of fascist repression that emerged during the Spanish Civil War and the dictatorship that followed it. Due to the lasting effects of Spain's Amnesty Law, which prohibits defining Franco's victims as victims of crime, these exhumation projects exist at the unruly boundaries of legal procedure. In the absence of courts equipped to manage the evidence exhumed and produced in these endeavors, photographs documenting the forensic process are not sequestered by the law. Instead, they are made to be seen. Drawing on what the author describes as subjunctive forensics, she analyzes the emergence of new bodies of knowledge -or what could be called the forensic archive- in order to understand how visual evidence that straddles the scientific and the political, particularly photography, is produced, circulated and safe-guarded in contemporary Spain. Drawing on ethnographic research and the experience of photographing mass grave exhumations, the author explores how shared forms of seeing are produced, acquired, and shared among the community of practice surrounding historical memory work. By focusing on how professional and skilled visions are constituted, the article argues that it is in the production, circulation, and display of forensic photography that Spaniards visualize an uncomfortable past while also imagining alternative political futures.
\end{abstract}

\section{Keywords}

Vision; photography; forensic science; historical knowledge production; evidence.

\section{Summary}

1. INTRODUCTION: AN AERIAL VIEW. 2. SUBJUNCTIVE FORENSICS \& PROFESSIONAL VISIONS: SEEING THE PAST, ENVISIONING THE FUTURE. 3. TO STAND WATCH: PHOTOGRAPHING FORENSICS OR HOW I LEARNED TO SEE FORENSICALLY. 4. SHARED VISIONS: PHOTOGRAPHY AND THE PRODUCTION OF KNOWLEDGE. BIBLIOGRAPHY

* This article has received funding from the European Union's Horizon 2020 research and innovation program under the Marie Sklowdowska-Curie grant agreement No 895197. 
Resumen. Durante dos décadas, los familiares de las víctimas del franquismo han recurrido a la ciencia forense para desenterrar diversas formas de evidencia que arrojan luz sobre la mecánica de la represión fascista que surgió durante la Guerra Civil española y que continuó a lo largo de la dictadura franquista. Debido a los efectos duraderos de la Ley de Amnistía, que prohíbe definir a las víctimas de Franco como víctimas de un delito, estos proyectos de exhumación existen al borde de los límites cambiantes y flexibles del procedimiento legal. Tomando en cuenta la ausencia de tribunales equipados para manejar las pruebas exhumadas y producidas en estos esfuerzos, las fotografías que documentan la labor forense no son secuestradas por la ley. En cambio, están hechas para ser vistas. La autora introduce el concepto de la ciencia subjuntiva para analizar el surgimiento de nuevos cuerpos de conocimiento que componen lo que ella llama el archivo forense. Este mismo concepto también ayuda a comprender cómo la evidencia visual fotográfica que ocupa simultáneamente espacios científicos y políticos es producida, circulada, cuidada y salvaguardada en la España contemporánea. Basándose en métodos etnográficos y su propia experiencia fotografiando las exhumaciones de fosas comunes, la autora explora cómo se producen, se adquieren y se comparten miradas compartidas entre aquellos que componen la comunidad de práctica que rodea la labor memorialista. Al centrarse en cómo se constituyen miradas o "visiones" profesionales y hábiles, el artículo sostiene que es a través de la producción, circulación y exhibición de la fotografía forense como los activistas de la memoria en España visualizan un pasado incómodo y al mismo tiempo imaginan futuros políticos alternativos.

Palabras clave. Modos compartidos de ver; fotografía; ciencia forense; producción de conocimiento histórico; evidencia.
Laburpena. Azken bi hamarkadetan, frankismoaren biktimen senideek zientzia forentsera jo dute Espainiako Gerra Zibilean sortu zen eta diktadura frankistan jarraitu zuen errepresio faxistaren mekanika argitzen lagunduko duten ebidentziak lurpetik ateratzeko. Amnistiaren Legearen ondorio iraunkorrak direla-eta, zeinak Francoren biktimak delitu baten biktima gisara definitzea debekatzen baitu, exhumazio-proiektu horiek legezko prozeduraren muga aldakor eta malguetatik hurbil daude. Kontuan izanik ez dagoela auzitegirik hilobietatik ateratako eta ahalegin horietan lortutako frogak maneiatzen duenik, legeak ez ditu bahitzen lan forentsea dokumentatzen duten argazkiak; aitzitik, jendeak ikusteko egiten dira. Egileak zientzia subjuntiboaren kontzeptua proposatzen du berak artxibo forentsea deritzona osatzen duten ezagutza-gorputz berrien sorrera aztertzeko. Kontzeptu hori bera lagungarria da ulertzeko nola ekoizten, zirkulatzen, zaintzen eta babesten den Espainia garaikidean ikusizko ebidentzia, argazkigintza alegia, aldi berean espazio zientifikoak eta politikoak betetzen dituena. Bai metodo etnografikoetan eta bai hobi komunen exhumazioen argazkiak egitetik lortutako esperientzian oinarrituta, egileak aztertzen du nola sortzen, eskuratzen eta konpartitzen diren lan memorialistaren inguruko komunitatea osatzen dutenen arteko ikuspegi partekatuak. Begirada edo "ikuspegi» profesional eta trebeak nola eratzen diren aztertzearekin batera, artikuluak dio argazki forentseen ekoizpenaren, zirkulazioaren eta erakusketaren bidez Espainiako memoriaren ekintzaileek iragan deseroso bat ikusarazten dutela eta, aldi berean, etorkizun politiko alternatiboak irudikatzen dituztela.

Gako hitzak. Ikuspuntu partekatuak; argazkigintza; zientzia forentsea; ezagutza historikoaren ekoizpena; ebidentzia. 
... In that Empire, the Art of Cartography attained such Perfection that the map of a single Province occupied the entirety of a City, and the map of the Empire, the entirety of a Province. In time, those Unconscionable Maps no longer satisfied, and the Cartographers Guilds struck a Map of the Empire whose size was that of the Empire, and which coincided point for point with it. The following Generations, who were not so fond of the Study of Cartography as their Forebearers had been, saw that that vast Map was Useless, and not without some Pitilessness was it, that they delivered it up to the Inclemencies of Sun and Winters. In the Deserts of the West, still today, there are Tattered Ruins of that Map, inhabited by Animals and Beggars; in all the Land there is no other Relic of the Disciplines of Geography.

Suarez Miranda, Viajes de varones prudentes lib. IV, cap. XLV, Lérida, $1658^{1}$

\section{Introduction: an aerial view}

On a Thursday afternoon in September 2010, the Puerta del Sol Plaza in downtown Madrid rumbled with the daily influx of pedestrians who crisscrossed through the public square, initiating their commutes back home. At the center of the plaza, amidst the after-work frenzy, members of the Plataforma contra la Impunidad del Franquismo clustered together near the large statue overlooking the bustling thoroughfare. Exchanging warm embraces and the occasional chuckle, the growing crowd of memory activists rhythmically chattered as they pulled laminated placards and posters from their backpacks and purses. Soon after, the cluster of men and women morphed into a solemn procession. Walking in pairs or groups of three, members of the Platform slowly circled around the plaza's innermost fountain. As they progressed, they lifted large sticks with black, white, and sepia-toned portraits tacked to their edges. The event, then in its eighteenth week, was part of a growing repertoire of performative tactics employed to call public attention to the lasting effects of violence experienced under Francisco Franco's long dictatorship (1939-1975). Although, at the time, these weekly manifestations were relatively new, they were uncannily recognizable as a local iteration -perhaps even, an intentional imitation- of the famous Thursday walks made by the mothers of Argentina's disappeared, who since the late 1970s have diligently made present their missing children by parading photographic images of desaparecidos in key plazas throughout the country ${ }^{2}$.

1 Borges, 1999, p. 325.

2 Taylor, 1997, pp. 183-189. 
On this particular Thursday, Spanish memory activists would stray from custom and implement a new way of making present and visible the traces of 20th-century fascist violence. As the Puerta del Sol grew heavy with the daily onslaught of commuters and passersby, members of the Platform unrolled a life-size aerial photograph of an unearthed mass grave ${ }^{3}$. Within minutes, the intermingled limbs and uncomfortably twisted spines of twenty-nine skeletons were plastered onto the plaza's uneven cobblestone surface. Once the haunting photograph was completely unfurled, those carrying photographs of the disappeared broke off from the rhythmic train of people solemnly circling around the plaza. As if securing the perimeter of a crime scene, they approached the image and fixed it to the stony ground by placing the poster-size portraits of their disappeared kin around the border of the artificial mass grave, artfully framing an equally artful superimposition of human remains frozen in a state of disarray. Like the trueto-scale map described by Jorge Luis Borges in his short story «On Exactitude in Science» ${ }^{4}$, the life-size photograph reproduced the scene of a forgotten crime with scalar precision.

Originally taken in 2007 during the La Andaya exhumation in the Province of Burgos ${ }^{5}$, the shocking photograph of twenty-nine skeletons and the performative practices that made it suddenly appear in Madrid's most transited public square provide a rich entryway into the complex world of contemporary Spanish memory politics ${ }^{6}$. The visibility of forensic labor -used to unearth the remains of those who fell victim to Francoist repression- stands in stark contrast to the culture of forgetting fortified during the transition to democracy, which began after Francisco Franco's death in 1975. Championing amnesia as a political and social safeguard against the resurgence of ideological dissent and community violence, the Transición promoted forward movement over individual and collective desires to look back. After more than 35 years of authoritarian rule, Spain's political elite faced a new panorama marked by uncertainty, uncharted territory that was institutionally unfamiliar. In this context, both left and right hailed conciliation and consensus as strategies for securing and modernizing the nation.

3 Junquera, 2010.

4 Borges, 1999, p. 325.

5 It is important to note that four mass graves were exhumed at La Andaya in Burgos. Graves 1-3 were exhumed in the summer of 2006, and Grave 4, which appears in this photograph, was exhumed the following summer. Since these exhumations are connected and linked to the same investigation, I use exhumation in the singular to refer to all four mass graves. See Ministerio de la Presidencia, Relaciones con las Cortes y Memoria Democrática, 2020.

${ }^{6}$ It is important to note that this photograph (see p. 151) is a composite of 7 zenith angle images that were later stitched together in Photoshop, by its author. The photograph was not taken from an aircraft or flying object. I use «aerial» to refer to the bird's eye point of view that the composite photograph communicates. 


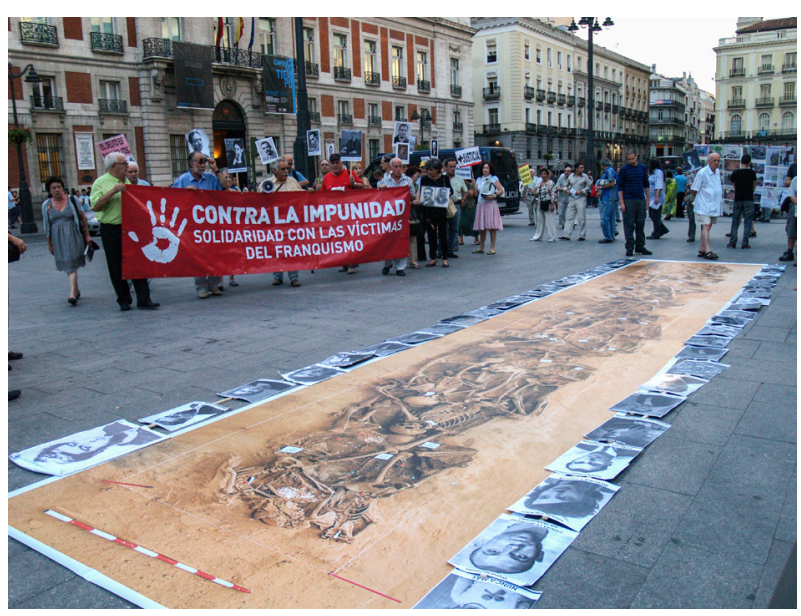

Figure 1. The La Andaya aerial photograph stretched out in the Puerta del Sol Plaza in Madrid. Photograph courtesy of Óscar Rodríguez Alonso.

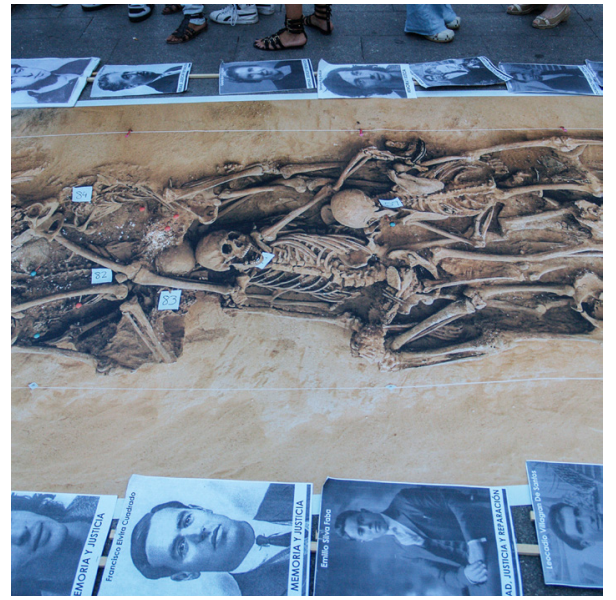

Figure 2. A close-up of the life-size image. Photograph courtesy of Óscar Rodríguez Alonso.

The ability to forget -or rather, to «disremember» ${ }^{7}-$ was quickly positioned as the magical cure-all that could facilitate political and social accord in a context marked by profound, deeply ingrained forms of ideological division. However, for those who suffered the social and economic marginalization that resulted from the death of their kin, the Transition further reinforced the silence that had pervaded everyday life under Franco. Time marched on, and the generational distance from dictatorial repression expanded, further reinforcing a pact of silence. The worlds of absence that victims' kin inhabited during the regime were soon matched by an increasing dearth of knowledge regarding the lives of those who experienced political violence firsthand. It is from within this context of silence, absence, and disinformation that the aerial photograph of the La Andaya mass grave becomes heavy with meaning. It is evidence of a crime that continues to be unrecognized by the Spanish state and its courts of law, visual proof of events that remain un-seeable -unknowable- to most Spaniards, including those who transited through the Puerta del Sol on that warm Thursday night in early September.

I start my analysis with a description of this image because it points to the important, yet complex, role that forensic photography plays in collective attempts to evidence the violence experienced during the Franco regime. It also makes visible the «labors of memory» ${ }^{8}$ that have slowly, but persistently, chipped away at

$\begin{array}{ll}7 & \text { Resina, 2000, pp. 1-15. } \\ 8 & \text { Jelin, } 2003\end{array}$

8 Jelin, 2003. 
the pact of silence and the culture of consensus that have held a strong hold over public debates regarding Spain's recent past since the transition to democracy. Finally, it reveals how images of this kind are animated in the making and staking of claims to alternative historical truths. However, this particular photograph, despite its multiple «social lives» ${ }^{9}$ is a single image of thousands more, that together constitute a vast and unruly collection, a visual archive, that documents the many mass grave exhumations carried out in Spain over the last two decades. It is this immense photographic corpus of bone imagery, this forensic archive, and its significance within the historical memory movement that I unpack in this essay.

The Spanish historical memory movement is a grassroots civil society led initiative that since the year 2000 has used forensic science as a tool for undoing the cultural, indeed political, silence surrounding the war and its aftermath. The movement is highly complex and locally specific, a heterogenous, at times, disordered phenomenon that must be understood in terms of territorial strugǵles that play out differently on municipal, provincial and national levels. As noted by Francisco Ferrándiz and Alejandro Baer, the local uptake of forensic methods, the proliferation of exhumation projects, and their articulation with the historical memory movement coincided with the emergence and growth of digital imaging technologies ${ }^{10}$. Initially carried outside the purview of the law, exhumations were methodically recorded and documented by forensic teams. They were also photographed by a growing community of memory activists: anthropologists and victims' kin; skilled photographers and amateur volunteers; journalists and researchers; artists and documentarians; and the many others committed to revealing and re-narrating local histories. While exhumations have been carried out officially, often with the support of the regional or central governments, they have not been subject to judicial processes. As such, many of the photographs produced in these endeavors -thousands of images that are often indistinguishable to the untrained eye- have been produced and circulated, kept and displayed.

As a consequence, the forensic archive is a very particular kind of image collection that perhaps defies how we typically define, conceive, or even imagine, an archive to be. Disconnected from specific sites of accumulation, the forensic archive is often decentralized and on the move. Digital files reside on hundreds of hard drives; while others have been centralized on websites and databases ${ }^{11}$. Images of mass graves are produced, circulated, displayed, and appropriated. They

9 Appadurai, 1986; Pinney, 1997.

${ }^{10}$ Ferrándiz and Baer, 2008.

11 The most recent example of this kind of online collection of photographs is the digital archive of photographs by Óscar Rodríguez Alonso, currently housed on the Aranzadi Sciences Society website: https://sites.gooǵle.com/aranzadi.eus/exhumaciones/inicio 
are published, shared, and re-used. They are often, at times problematically, decontextualized in this frenzied movement. At others, they are subject to multiple forms of inscription, description, and catalogization ${ }^{12}$. The dislocated and unruly character of this image collection reflects the precarity that surrounds historical memory work in contemporary Spain, where uneven public funding schemes, legal roadblocks, and irregular institutional support has made it difficult, indeed impossible, to articulate shared, uniform approaches to addressing Spain's violent past.

In calling this body of imagery an archive, I seek to accentuate the ways in which these images are collected, cared for, animated, and used. As in any archival collection, photographs of mass graves are guarded and preserved; there is a sense -a hope- that they will be useful at a future time. They are used to illustrate emergent narratives, to activate performative actions, and to feed cultural interventions and research initiatives. They serve as illustrations to forensic reports that are returned to victims' kin, submitted to public offices, and sent to international human rights organizations ${ }^{13}$. Despite the vast, refractory character of this image collection, describing it as an archive helps to accentuate the kinds of logics or forms of «common sense» ${ }^{14}$ that structure how photographs are grouped and described. It also draws our attention to the potentiality of these images as visual evidence that can be narrated and presented to the Spanish courts of public opinion. Regardless of who snaps the lens, images from the forensic archive are taken with a particular objective in mind: they are the product of documentation practices that seek to freeze an ephemeral moment in time in which discarded human remains are revealed, when a forgotten or unrecognized crime is made visible and seeable for the first time.

The immense corpus of forensic photographs produced in Spanish exhumation projects have led many to identify a specific iconography, unique to the

12 These observations about images' circulation, contextualization, and decontextualization originates from my ethnographic work with photographers, forensic experts, anthropologists, and memory activists. While it is hard to track these processes, the photograph of the La Andaya exhumation is a good example of how images can move across these different regimes of signification. Taken by a member of the Aranzadi team, the image has been used to illustrate forensic reports, where it has been contextualized. It has also been included in the exhibition «Exhuming Mass Graves, Recuperating Dignity», which has circulated nationally and internationally. And, as I narrate it has also been displayed in public space, where it is decontextualized from the mass graves' history.

${ }^{13}$ It is important to note that between 2000 and 2006, exhumation projects were carried out with varying deǵrees of support from local, regional, and national governments. Between 2006 and 2011, exhumations received official support, as well as financial backing, from the President's Ministry. In response to economic cuts, exhumations carried out after 2011 often received support from regional autonomous governments. Forensic reports have been generated for all projects that have received public funding. Additionally, those reports generated between 2006 and 2011 are included in the Centro Documental de la Memoria Histórica, which is part of the Archivo General de la Guerra Civil en España, see Turrión García, 2020, pp. 162-188.

14 Stoler, 2009, p. 3. 
context of historical memory work in Spain. Both indistinguishable and shockingly specific bone imagery has come to represent not only the labor of forensic investigation, but also the particularities of Spanish memory debates, where the crimes of the past have been made visible, but whose implications are not fully legible or recognized by the State. Etymologically, iconography comes from the bringing together of the Greek words eikon, meaning likeness, and graphia, meaning writing. In the $17^{\text {th }}$ century the term was used to describe a sketch or description, a way of capturing on paper a person or object's likeness. To speak of «forensic iconography» is to identify the emergence of a new body of images, a canon of photographs unified by a series of shared aesthetic characteristics. However, if we go back to the roots of the word itself, to what iconography means, rather than what it suggests - a forensic writing of likeness, a record of resemblances- this term obfuscates the complex visual worlds that surround Spanish exhumation projects, and more importantly, the labor of recuperation, through which photographic evidence is mobilized in order to make meaning about the past. It renders invisible the processes by which images are produced and circulated across «evidential regimes» ${ }^{15}$ and, by extension, the complexity of the roles that these seemingly technical images play in the production of knowledge.

In this article, I argue that making sense of the forensic archive and the proliferation of forensic photography in contemporary Spain requires a shift in focus. Rather than unpacking what images represent, I will consider how they produce «shared ways of looking» ${ }^{16}$. Drawing on Nicholas Mirzoeff's description of a counter-history of visuality, in which «the right to look» ${ }^{17}$ is claimed in order to accentuate the power dynamics that structure how images are made to mean, I argue that memory activists, including professional and amateur image-makers, are part of a broad «community of practice» ${ }^{18}$ that learns to see forensically. It is in seeing like scientists that image-makers and memory activists educate the eye -train their vision- in ways that reveal the historical and political valence of unearthed remains. In order to do this, I will start by describing how forensic practice in contemporary Spain inhabits what I call the subjunctive mood, which allows photographic evidence to straddle multiple temporalities: past, present, and future. Subjunctive forensics, I argue, introduces those who observe mass grave exhumations to new ways of seeing - to alternative "professional visions» ${ }^{19}$ that allow them to become part of this community of practice. I will continue by

\footnotetext{
15 Crossland, 2013; see also Renshaw, 2017.

${ }^{16}$ Grasseni, 2018, p. 4.

17 Mirzoeff, 2011, p. 2.

${ }^{18}$ Lave and Wenger, 1991; Wenger, 1998.

${ }^{19}$ Goodwin, 1994, p. 606.
} 
reflecting on my own experience photographing exhumations. It is by learning to see forensically, I posit, that I could understand not only what photographs of human remains evidence and represent, but how they open up new ways of imagining alternative political futures. Drawing on ethnographic observations and photographic practice, I will describe how I acquired a particular kind of professional vision -a forensic gaze- that allowed me to understand the kinds of knowing that emerge in exhumation projects.

\section{Subjunctive forensics \& professional visions: seeing the past, envisioning the future}

The aerial photograph of the La Andaya exhumation was originally taken with a specific forensic purpose in mind: to accurately record the anatomical position of the human remains being uncovered. The image is the product of an expansive, detailed set of forensic practices -indeed, a carefully crafted methodology- that seeks not only to recover and recuperate victims' corpses, but also to document the process through which this evidence is revealed. Once in the laboratory, forensic experts bring together these layers of evidence in order to determine the identity of those who were killed and the circumstances surrounding their deaths. They use this kind of image as a way of stepping back in order to see the larger picture, a way of visualizing and imagining the violent acts that produced a particular crime. The aerial view of the photograph -like the aerial view of the historian- provides distance and perspective, a kind of widened interpretative frame that is relatively new in contemporary Spain. Whether blown-up and put on display in life-size proportions or inserted into a forensic report as a way to

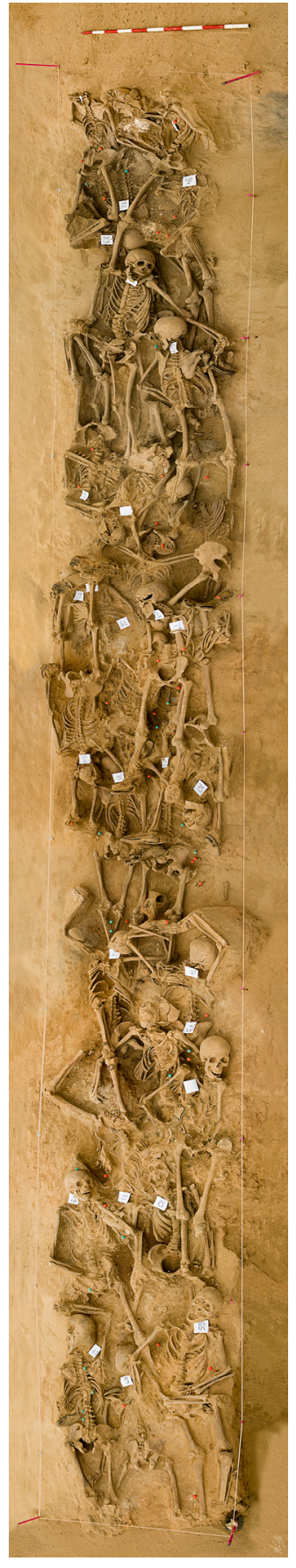

Figure 3. A view from above: Zenith angle photograph of Fosa 4, La Andaya. Image made in 7 parts and stitched together in Photoshop. Photo Courtesy of K-ito, Aranzadi Sciences Society. 
frame, explain, and contextualize the minute, detailed forms of data collected by forensic teams, the image is both expansive and exact. Like in Borges' short story, highlighted at the beginning of this article, the tension between immensity and precision is as unsettling as it is haunting.

In his story «On Exactitude in Science», Borges conjures a fantastical empire where the art of cartography has become so meticulous and so accurate that the geographic territory in question can only be represented through is precise, scalar reproduction. While certainly a literary exercise in imagination, the story is also a reflection, indeed a critique, of the relationship between modern science, its focus on modes of measurement, and the forms of power embedded in the possibilities afforded by scientific precision. Borges asks readers to consider what might be lost in the pursuit of an exactitude that only serves to replicate the world in its precise form and shape. However, when victims' kin display the life-size aerial photograph of the La Andaya mass grave, the exactitude of science described by Borges is, instead, deployed as a call to action, a rallying cry to undo the structures of power that maintain historical silence in post-Franco Spain. As memory activists unfurl the photograph, they are -in effect- rolling back the curtain, revealing and making visible forms of fascist violence that have long been invisible in Spanish society. While it is important to memory activists that this carefully crafted forensic image reveals the scientific process and its commitment to measurement and methodical observation, the photograph's exactitude is mobilized with very different objectives in mind. Translating this scientific data, that is contextualizing it and narratively piecing together the different forms of evidence that are unearthed, recovered, and revealed in these projects, are part and parcel of the arduous labor exerted to craft new bodies of historical knowledge in contemporary Spain.

As in Borges' story, the exactness promised by forensic science is not to be discarded. By beginning this story with a life-size aerial photograph stretched out and made to be seen, I want to draw readers' attention to how the evidence extracted through forensic practice is made to do a particular kind of work. In this sense, the image being described is perhaps less like Borges' gargantuan map and more akin to the eighteenth- and nineteenth-century scientific atlas images described by Lorraine Daston and Peter Galison in their book Objectivity ${ }^{20}$. In their text, the authors approach the scientific atlas as a source of insight into how epistemic virtues and empirical work produced new forms of understanding and conceiving of scientific practice. They argue that, «scientific atlas images are images at work $»^{21}$. In other words, compendiums of images are not simply representa-

\footnotetext{
${ }^{20}$ Daston \& Galison, 2007.

${ }^{21}$ Daston \& Galison, 2007, p. 19.
} 
tions of the natural world plotted onto paper; instead, they are the «working objects ${ }^{22}$ that train scientific collectivities to see. By tracking scientists' concerns about how to objectively transform the natural world into image form, the authors draw attention to how images have been used to train the scientific eye and to mold the scientific virtues that push forms of empirical research. In Spain, the photographs that make up the forensic archive are deployed to train the Spanish public to see and view recent history in different, more nuanced ways. In order to understand how this vision -these shared ways of seeing- are produced, it is important to understand the particularity of forensic practice in this context.

The application of forensic methods to the study of Spain's recent past occurs at the unruly boundaries of legal procedure ${ }^{23}$. Due to the lasting effects of Spain's post-dictatorship Amnesty Law, exhumation projects are not overseen by judicial entities. Instead, they are carried out «as if» they were official forensic investigations in which scientific evidence and forms of documentation could be submitted and validated by courts of law. As such, these initiatives, I argue, inhabit the subjunctive mood -a state of being in which forensic practice is carried out as if it could be recognized by the law ${ }^{24}$. It is the «as if», "para-forensic» ${ }^{25}$ status of exhumations and, by extension, historical memory work that creates the forensic archive. It also complicates how its contents are presented to public forums ${ }^{26}$. I use to term subjunctive forensics to explain the epistemological flexibility of the objectivity claimed in exhumation projects. Forensic photography captures and displays science in action. These photographs are also indicative of a particular «professional vision ${ }^{27}$, a way of seeing and understanding unearthed remains in ways that make it possible to produce meanings from the technical, at times cold images produced in documenting these events. In order to understand these ways of seeing and the processes by which photographs of bones are made «to speak beyond the grave» ${ }^{28}$, it is important to unpack the unique ways in which forensic science is mobilized in contemporary Spain.

22 Daston \& Galison, 2007, p. 19.

${ }^{23}$ It is important to note that throughout this text I am referring specifically to the use of forensic methods to study Francoist repression. Forensic methods have been applied to analyzing other examples of crime from the recent past.

${ }^{24}$ It is important to note that since 2000, exhumations have been carried out by teams that follow international and national protocols specific to contexts of mass violence. Exhumations carried out before 2000, mostly during the late 1970s and early 1980s, did not use scientific methods or practices. My argument here is that exhumations in Spain are not judicialized, and as such photographic documentation -indeed, evidence- is presented to public forums in unique ways.

${ }_{25}$ Holmes and Marcus, 2005.

${ }^{26}$ Keenan and Weizman, 2012, p. 28.

${ }^{27}$ Goodwin, 1994.

${ }_{28}$ Joyce and Stover, 1991, p. 144. 
Subjunctive forensics refers to a particular set of administrative, legal, and even cultural impossibilities. It emphasizes the inability of forensic knowledge to seamlessly enter into public discussions about the past. However, I also argue that subjunctive forensics invests the objects and narratives recuperated and produced in these endeavors with an ability to project forward. With evidence barred from entering courts of law, those who engage with the images that make up the forensic archive must always look towards future possibilities. They must imagine new alternative futures in which the fruits of their labor can be woven into shared understandings about the past. In this sense, subjunctive forensics provide a realm of possibility, where photography is intricately entangled in knowledge production practices that carve out a new field of common sense where the tensions between memory and forgetting -between absence and presence- can allow for a more multi-vocal rendition of the past and a more horizontal and democratic mode of imagining the future.

Subjective forensics requires experts to contextualize the contents of the forensic archive in order to produce narratives that are often times far from scientific. The same goes for memory activists, victims' kin and photographers themselves, who are all deeply invested in the labor of recuperation. The absence of a judicial forum requires that scientific knowledge be made knowable and understandable to a more diverse public forum requires that attention be paid to how narrative labor activates and makes sense of photographs and the practices that produce them, how it makes these cold images something that is much more. So, while scientific claims to objectivity point to how evidence is unearthed and mobilized -how it is invested with narrative potential and truth-bearing abilities so that new forms of knowledge can be produced, the subjunctive forensics help explain why claims to objectivity are projected towards the past, but also towards an alternative political future marked by belonging and democratic change.

Subjunctive forensics is a para-practice where experts and non-experts collaborate in localizing and unearthing human remains. As I have argued elsewhere, exhumation projects require the bringing together of multiple forms of knowledge, particularly techno-scientific expertise and kin-based narratives, so that different forms of evidence -including, archival records, family histories, and forensic know-how- can be mobilized to find mass graves and make sense of their material contents ${ }^{29}$. The State's uneven, at times, inconsistent presence in these endeavors and exhumations' position outside official legal processes means that victims' kin, anthropologists, photographers, and other interested parties can participate in these events. I argue that these actors, or memory activists, constitute what Jean Lave and Etienne Wenger describe as a «community of prac-

${ }^{29}$ Douǵlas, 2014, pp. 9-10. 
tice $»^{30}$. Their shared concern for uncovering evidence of political violence is also reinforced by their participation in exhumation projects. As I will describe in the next section, this participation is rooted in acts of observation. Here, I argue that subjunctive forensic practice recruits participants into a way of seeing that solidifies their role as memory activists. In learning to see exhumed remains, participants acquire a scientific gaze, but also new ways of knowing that shape how they understand the past and its roles in the present.

Anthropologist Charles Goodwin coined the term «professional vision» to describe «socially organized ways of seeing and understanding events that are answerable to the distinctive interests of a particular social group ${ }^{31}$. Examining two arenas of professional activity, including archaeological excavation and legal argumentation, he argues that three specific practices -coding, highlighting, and producing or articulating material representations- bring into being ways of seeing that «create the objects of knowledge that become the insignia of a professional craft» ${ }^{32}$. In his description of archaeological practice, coding refers to the perceptual and cognitive labor that experts exert in categorizing the color and texture of the earth. This process of describing and categorizing dirt transforms observations into «objects of knowledge ${ }^{33}$ while also unifying data and erasing uncertainty. Highhlighting, in contrast, occurs when archaeologists mark the ground when locating unique features, changes in the earth's surface, or shifts in coloration. By marking these details, an archaeologist makes them seeable to other experts. Highlighting indicates, identifies, and delineates the emergence of evidence to be analyzed. Finally, transforming observations into material and visual representations allows archaeologists to plot their findings. One example of this is the creation of diagrams and maps, a practice which allows archaeologists to transform observations and data into a single visual representation that communicates what has been discovered. Echoing Bruno Latour and Steve Woolgar's discussion of inscriptions and their role in organizing scientific knowledge $^{34}$, Goodwin argues that this transformation of observation and knowledge into representations is key to the constitution of archaeology's professional vision. Toǵether, coding, highhliǵhting, and representinǵ produce a shared approach or vision that gives an archaeologist «the power to speak as a professional» ${ }^{35}$.

Photographs of unearthed human remains and the broader forensic archive point to how the memory activists in Spain are creating a new inscription, an

\footnotetext{
${ }^{30}$ Lave and Wenger 1991. See also Wenger, 1998

31 Goodwin, 1994, p. 606.

32 Goodwin, 1994, p. 606.

33 Goodwin, 1994, p. 606.

${ }^{34}$ Latour and Woolgar, 1979.

35 Goodwin, 1994, p. 624.
} 
alternative visual atlas that more adequately describes and brings into view the worlds of absence that have pervaded the lives of victims and their kin. These images seek to make unrecognized experiences palpable, knowable to a wider Spanish public. Just as Daston and Galison describe the push and pull of changing definitions of scientific objectivity, I argue that the historical memory work implicit in the constitution of the forensic archive is indicative of a particular kind of professional vision that legitimates the labor of recuperation while also framing this evidence as indicative of alternative forms of historical knowledge. These shared way of seeing can be deployed to contest other professional visions and official historical narratives, making it possible to stake claims that are otherwise inconceivable. Subjunctive forensics and the professional visions that these practices produce make it possible to produce the forensic archive that, once displayed, establish a new common ground on which to stand -a common ground where mass graves are made present, rather than kept absent and invisible. It is by collectively seeing this uncovered past that it becomes possible to envision and make claims to an alternative political future.

\section{To stand watch: photographing forensics or how I learned to see forensically}

There is a verb in the Spanish language that alludes to ideas of both surveillance and care. Vigilar can mean to watch, but also to be attentive; to monitor as well as to observe; to police and to stay alert. It is a verb that implies an act of vigilance, to hold vigil. During fieldwork, I often scribbled this word into the margins of my notebook, deploying it to describe something that I could perceive, but not yet explain. I used it, often unknowingly, to capture and record the sense of care and attention that were palpable at exhumation sites ${ }^{36}$. It was a kind of impromptu shorthand that could be employed to make note of people's interactions with the dead; with the objects and narratives being uncovered; with the earth and the surrounding landscape.

While professional vision helps us understand how photographs, like the lifesize rendition of the La Andaya mass grave, are deployed to evidence alternative bodies of knowledge, understanding how individuals are inducted into these shared forms of seeing -these communities of practice- make it possible to tease out how memory activists are trained to see mass graves in ways that are both technical and empathetic. In her work on vision, anthropologist Cristina Grasseni

\footnotetext{
${ }^{36}$ For descriptions of the kind of care exerted at exhumation sites, see Wagner, 2008; Rosenblatt,
} 2015; and Renshaw, 2011. 
contests the idea that images and imaging technologies can be solely understood as mediators of meaning, power and knowledge. Paying attention to what Tim Ingold describes as «the enskillment of vision» ${ }^{37}$, Grasseni situates the «training of vision in professional, scientific, and everyday situations» as a site for unpacking how knowledge is produced through visual artifacts ${ }^{38}$. By dwelling on «the actual processes through which people are trained into communities of practice by learning to relate to certain tools, narratives and categories», Grasseni draws attention to the active, agentive role that local contexts and communities play in the constitution of knowledge.

Mobilizing this idea of «skilled visions», I propose that moving from a discourse of forensic iconography to a more complex field of representation where photographic documentation of mass grave exhumations is understood to operate within the broader arena of recuperation, requires us to reflect on the very processes by which actors engaged in exhumation projects learn to see forensically. In other words, in order to understand how the forensic archive is made to mean, we must understand how memory activists learn to see like scientists. It is by shifting our focus away from the image and what it represents and by moving towards an analysis of forensic forms of seeing, that we can access the «local knowledge ${ }^{39}$ and expertise that mobilize photographic evidence both within and outside the confines of scientific practice. Photographing forensics is a way to incorporate oneself into the subjunctive mood of Spanish exhumation projects, where evidence is understood to show what was, but also what could be. By extension, learning to see forensically is a way of becoming part of a community of practice where the value of photographic evidence does not lie in what the image represents, but rather in the knowledge -both historical and scientific, both sensorial and emotional- that is accrued in its production and later in its circulation and display.

$$
* * *
$$

In the summer of 2014, an interdisciplinary team of forensic experts and student volunteers faced the task of exhuming three mass graves in an area known as Monte de Estépar in the Province of Burgos ${ }^{40}$. A fourth grave had been located the day before the exhumation began. Due to time restrictions, the team decided that

${ }^{37}$ Ingold, 1993, p. 221. See also Ingold, 2000; Grasseni, 2007, p. 3.

${ }^{38}$ Grasseni, 2007, p. 10.

${ }^{39}$ Geertz, 1985; Geertz, 1992.

${ }^{40}$ This exhumation was led by archaeologist Juan Montero-Gutiérrez, with the collaboration of the Aranzadi Sciences Society and students from the University of Burgos. See Montero-Gutiérrez, 2017 for more information. 
they would return to excavate the fourth gravesite in the following months. There simply was not enough time to get the job done. As the exhumation progressed and buckets of dirt and debris were removed, individual skeletons became more perceptible. Differences in the character and composition of each grave became more visible. By day three, it was clear that one of them, Fosa \#2, was by far the most visually arresting. The position of the 26 skeletons made it easy, too easy, to imagine how the bodies had been discarded. There appeared to be no order in the skeletons' placement. Everyone, even a non-expert like myself, could see that they had been carelessly thrown on top of one another ${ }^{41}$. The violence was palpably visible. I could see it in the wrists that had been tied behind backs, the twisted legs that jutted from the jumbled mounds of remains and the pierced craniums. The more I focused my gaze, the more apparent it became: the random placement of skeletons, the jumbled piles of remains, also pointed to a pattern of intentional and violent neglect. At some point in the afternoon, I was standing at somewhat of a distance from the grave, under the shade of an oak tree, when a member of the local memory association looked at my camera. As our eyes met, she said: «Come over here, I want you to see something». We walked a few feet until planting our feet at the foot of Fosa \#2. «Can you see that»? she said, her hand pointing to the ground. «We are calling it El Grito». I looked at her face and followed her line of vision down to the right side of the grave. I could see that she was pointing to one of the skulls, its head back and mouth open. The arm bones just below the cranium were splayed out horizontally, as if the victim had fallen backwards into the grave, his face frozen in a permanent state of surprise. The scream, I thought, a nickname that was curiously appropriate, though uncomfortably macabre. My eyes were fixed on the skeleton below when I heard forensic experts discussing the contents of the different graves. In Fosa \#1, victims wore alpargatas, the makeshift espadrilles that were a common footwear choice for day laborers in the 1930s. In the other, the victims appeared to be wearing shoes. The rubber soles were still intact.

«Clearly», I heard an archaeologist comment, «they were making a distinction between the prisoners: the ones who worked in the fields and the ones who came from a higher socioeconomic context». I listened carefully, my eyes still veering towards the freshly nicknamed skeleton. If the military was conducting sacas from the Burgos Prison and if groups of prisoners were being organized

${ }^{41}$ It is important to note that historical and forensic research on Francoist violence has revealed that repressive campaigns during the war and the dictatorship deployed very specific kinds of violence. Both in Monte de Estépar and in La Andaya, mass graves were the product of sacas where victims were released from prisons and transported to sites of execution. See Montero-Gutiérrez et al., 2017, pp. 193-198. 
by class or profession, it might be possible to make connections between what we were finding in the graves and the lists of names extracted from the prison archive. There were most likely patterns regarding which victims were killed, during what time period, and their supposed political affiliations, alliances that were often connected to specific class divisions. My attention was pulled away from my thoughts as I heard the woman from the local memory association say: «You should really take a picture of this before they start packing up the bones. At this rhythm, most of this will be gone by the end of the day». She pointed gently to my camera. I lifted it to my line of vision and reluctantly began snapping pictures. The woman, satisfied with clicks of the shutter, patted my shoulder before walking away. I stayed at the foot of the grave for a few seconds before stepping down to the bottom level of the work area, where archaeologists and physical anthropologists continued to hunch over the jumble of skeletons, their hands swiftly brushing away excess dirt. One of the more seasoned team members came and stood by my side.

«El Grito, how about that»? he said.

«Well», I replied, «I suppose it does look like the person is screaming».

«Of course», he said. «But, you know that the open jaw, the fallen mandible, that is something that happened from inside the grave and over time. The bones here», he said, rubbing the back of his jaw with both hands, «they aren't connected by bony matter. It's all cartilage and muscle. So, with time, with the decomposition of the body, the jaw falls open. It has to do with how the body fell into the grave». I looked at him, perplexed. He gently grabbed my arm to bring me in closer. I followed his lead, crouching down so that I was just a foot or so away from the skeleton. He continued, «You see this individual is supine, or face up» He reached his arm, perpendicular to his body, and placed his hand flat so that his palm was facing the bright blue sky. «The others are pronated, or face down». He continued, this time turning his palm to face the skeletons below. «As a result, the disarticulation in the jaw is less perceptible. But, you know, I get it. I mean... it makes sense. Up or down, these guys were clearly thrown in carelessly». I slowly brought my camera back up to my line of vision. My colleague stood. He placed his hand on my shoulder and returned to work.

As he walked away, I snapped a few more pictures and then moved to the other side of the adjacent grave. I observed for a few minutes and then brought the camera back to my eye. I snapped the shutter a couple of times before walking closer to where team members and volunteers were working. I asked a young archaeology student to tell me what she could see. She described the gunshot wound that was clearly visible on the left side of the skull that she was examining. Moving her gaze down the length of the skeleton, she noted the disarticulation between joints that had been caused by the placement of the bodies. One on top of another, the bones were tangled and hard to distinguish. 


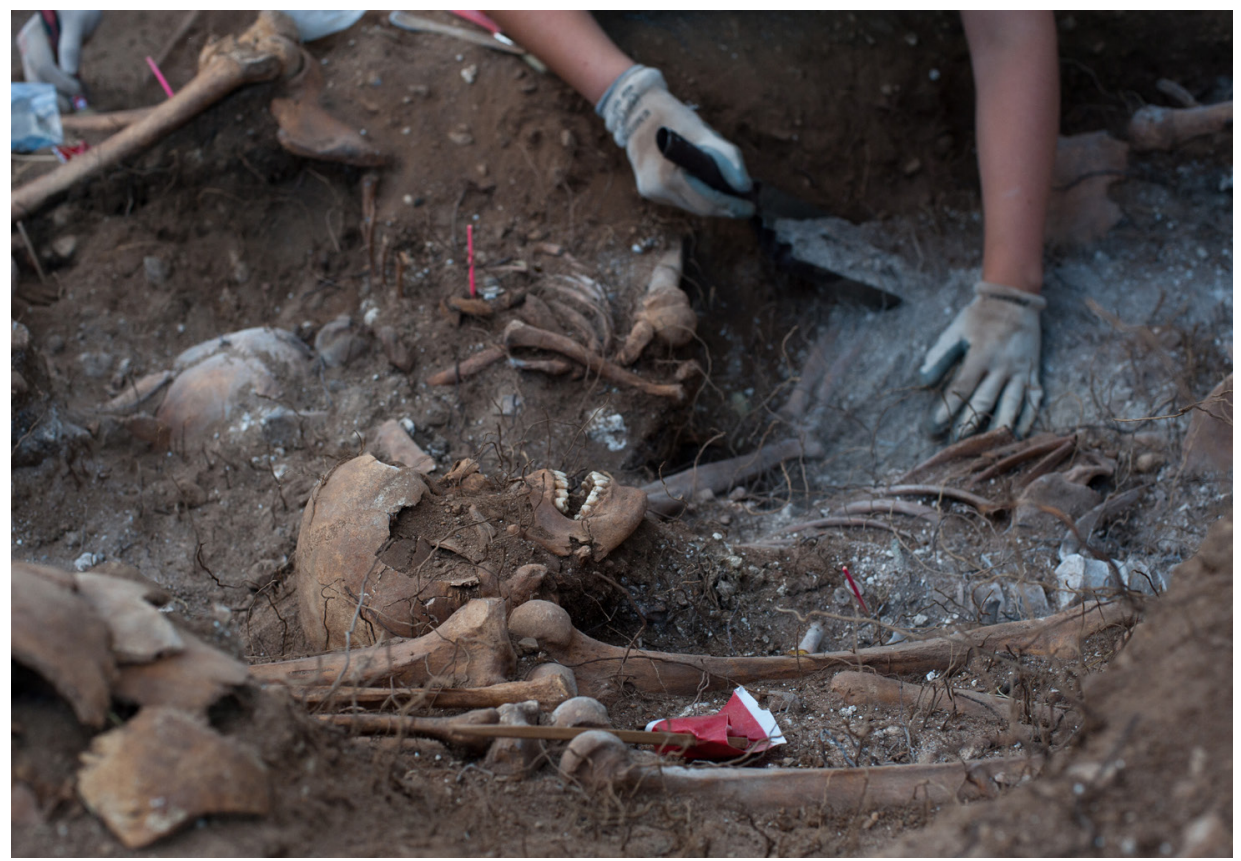

Figure 4. El Grito, Monte de Estépar, Summer 2014. Image courtesy of author.

I stood back, observing her gestures as she described the bones. I swiftly moved to the other side of the grave so that I was standing directly in front of her. I raised the camera once again and followed the movement of her hands as she described the placement of the skeleton. She spent some time detailing the size and shape of the pelvis bone, noting that the narrow angle below the pubic symphysis and the more vertical, heart shape of the ilium most likely indicated that the individual was male. As she spoke, I leaned in, trying to capture the expression on her face and the gentle way in which she guided her finger around the border of the pelvis.

It was through this kind of movement and engagement that I learned how to see forensically; how I came to understand the value of observation -both my own acts of vigilance as well as those exercised by my interlocutors in the field. Explanations of what was being uncovered and descriptions of how the contents of mass graves were being deciphered introduced me to shared ways of seeing that involved not only the gaze, but other forms of sensorial perception and the skills needed to connect graves' contents with other contextualizing clues. Taking pictures allowed me to experience the relationships that people developed with the evidence -both material and intangible- that was publicly 
unearthed in these initiatives, as well as the relationships that they developed with one another. Photographing forensics directed my attention to particular skeletons marked as significant and to what members of this community of practice deemed to be photographable. By zooming in, pulling details into the frame, then moving away, I also trained my vision, becoming more attune to the ways in which human remains were perceived and transformed into evidence, and to how narratives were brought into being. Finding the dexterity to move between proximity and distance, between the traces of violence that could be read on human bone and the historical context extracted from archives and testimonies, introduced me to the integral role that vision plays in producing knowledge. By learning to see forensically, I could begin to understand what forensic images could represent and their importance, like bones, which are, as Katherine Verdery notes, particularly efficient «symbolic vehicles» ${ }^{42}$. Perhaps more importantly, I could perceive how memory activists train their vision and how, in doing so, they produce shared forms of seeing that are fundamental to the processes of knowledge production that extend far beyond the foot of the grave.

Describing exhumations requires a long list of prepositions, like in, on, over, and around, that establish relationships between subject and object. These prepositions speak to the relational ways of seeing that are fundamental to exhumation projects. In my experience, becoming enskilled in particular forms of seeing situated me in relationship to mass grave exhumations, to unearthed human remains, and to forms of seeing shared by the community of practice integral to forensic labor. Learning to see like a scientist, I argue, is not only about understanding how bones are read. It is a way of training the eye and the senses in order to understand how forensic evidence can be connected to other narrative forms. How it can be both «of and for» something ${ }^{43}$; how it can represent something but also be deployed to produce new knowledge forms. This, in turn, highlights how images from the forensic archive, photographs seemingly unidentifiable to the untrained eye, are inscriptions that tell stories. They are narratives where science, historical knowledge, and testimony overlap. In this sense, forensic vision unlocks the worldviews that shape how forms of evidence -documents, bones, and aerial photographs- are made to mean. From over, on, and inside the grave, I acquired the skilled visions that allowed me to see how the growing corpus of forensic images that could be made to mean in a multitude of ways.

\footnotetext{
42 Verdery, 1999, p. 27.

${ }^{43}$ Csordas, 2004, p. 245.
} 


\section{Shared visions: photography and the production of knowledge}

In her analysis of Indonesian popular photography, Karen Strassler describes the «reflexive production and circulation of images» that facilitates imagining «social entities» and «training would-be national subjects» ${ }^{44}$. In a similar vein, forensic photography in Spain facilitates collective imaginings in which historical narratives are restructured to include the narratives linked to those resting in mass graves. Subjunctive forensics can be useful in revealing how the images that make up the forensic archive are simultaneously «marshaled as proof of the past» and "projected as shimmering visions of the future» ${ }^{45}$. It also points to how these technical images are more than the evidence they record. Like Strassler, who argues that Indonesians envision and produce the nation through photographic practices ${ }^{46}$, I posit that Spanish memory activists imagine and make alternative political futures through their engagements with imaging practices. Accessing how these imaginary acts takes place requires attention be paid to how forensic vision is learned and how, by extension, these shared ways of seeing further solidify a community of practice committed to acts of recuperation and to the production of new forms of historical knowledge. The professional vision produced in mass grave exhumations allows experts and non-experts professional and amateur image-makers- to partake in shared ways of looking that reinforce a particular approach to forensic labor, to visual and material evidence, and thus to a more multivocal rendition of the past. Consolidating this professional vision requires processes of enskillment -of training one's visionin ways that invests photographic images with the contextual information that make them much more than a visual record of human remains. Understanding the forms of knowledge -the kinds of historical re-narrations and future imaginings- that occur when images are produced, circulated, and displayed requires that attention be paid to the ways of seeing produced in the context of subjunctive forensics.

The forensic techniques and technologies deployed in mass grave exhumation projects does a particular kind of work that is everything but scientific. This argument does not seek to ignore forensic experts' staunch commitment to forms of measurement and observation. However, the evidence that is collaboratively produced in these endeavors is used to convince, persuade, and educate Spaniards about a collective history that many believe to have been erased from histo-

\footnotetext{
${ }^{44}$ Strassler, 2010, p. 4.

45 Strassler, 2010, p. 4.

${ }^{46}$ Strassler, 2010, p. 4.
} 
ry books and ignored by the State ${ }^{47}$. It is through this labor of narration and the making and staking of claims that forensic experts and memory activists produce knowledge that is at once scientific and historical, both objective and positioned. Seeing like a scientist, I argue, is a process in which members of this community of practice engage with experimentation and measurement, but also careful forms of observation that allows human remains to be invested with meaning that undoes Spain's culture of silence. These shared ways of seeing are a potent tool in shifting and complicating public understandings about the recent past. This ways of seeing -ways of knowing- allow forensic photographs to inhabit multiple epistemological worlds. The life-size aerial photograph of a mass grave, once unfurled and put on view, is indicative of shared ways of seeing. The same is true of the photographs that I took during field work and that now help me explain my analysis of what exhumations do in contemporary Spain. Together, these images and the visions that produce them, call our attention to how memory activists and other social actors activate the forensic archive in attempt to teach others how to see and, thus, how to reconceptualize Spain's past, present, and future.

\section{Bibliography}

Appadurai, Arjun, The Social Life of Things, Chicago, University of Chicago Press, 1986. Borges, Jorge Luis, «On Exactitude in Science», translated by Andrew Hurley, in Collected Fictions, 325, New York, Penguin Books, 1999.

Crossland, Zoe, «Evidential Regimes of Forensic Archaeology», Annual Review of Anthropology, 42, 2013, pp. 121-137.

Csordas, Thomas J., «Evidence of and for What», Anthropological Theory, 4, 2004, pp. 473-480. doi: https://doi.org/10.1177/1463499604047922

Daston, Lorraine, and Peter Galison, Objectivity, Cambridge, Zone Books, 2007.

Douglas, Lee, «Mass graves gone missing: Producing knowledge in a world of absence», Culture \& History Digital Journal, 3.2, 2014. doi: http://dx.doi.org/10.3989/ chdj.2014.022.

Ferrándiz, Francisco, and Alejandro Baer, «Digital Memory: The Visual Recording of Mass Grave Exhumations in Contemporary Spain», Forum: Qualitative Social Research, 9.3, 2008. doi: https://doi.org/10.17169/fqs-9.3.1152.

${ }^{47}$ In fact, much of the work carried out during the last two decades, together with historical work that emerged in the 1980s-1990s and continues today, demonstrates that this erasure and silence is being undone. The implication of national and regional governments in exhumation projects carried out since 2000, although uneven, is also an important shift. However, their continues to be a strong belief that experiences of victims and their kin have not been fully recognized or incorporated into national narratives regarding the recent past. 
Geertz, Clifford, Local Knowledge: Further Essays in Interpretative Anthropology, New York, Basic Books, 1985.

Geertz, Clifford, «Local Knowledge and its Limits», The Yale Journal of Criticism, 5.2, 1992, pp. 129-135.

Goodwin, Charles, «Professional Vision», American Anthropologist, 96.3, 1994, pp. 606633. doi: https://io.1525/aa.1994.96.3.02.a00100.

Grasseni, Cristina, «Skilled Visions: Between Apprenticeship and Standards», in Cristina Grasseni (ed.), Skilled Visions: Between Apprenticeship and Standards, London, Berghahn Books, 2007, pp. 1-19.

Grasseni, Cristina, «Skilled Vision», in H. Callan (ed.), The International Encyclopedia of Anthropology, 2018. doi: https://doi.org/10.1002/9781118924396.wbiea1657.

Holmes, Douglas, and George Marcus, «Cultures of Expertise and the Management of Globalization: Toward the Refunctioning of Ethnography», in Aihwa Ong, and Stephen J. Collier (ed.), Global Assemblages: Technology, Politics, and Ethics as Anthropological Problems, Oxford, Blackwell, 2005, pp. 3-21.

Ingold, Tim, «The Art of Translation in a Continuous World', in G. Pálsson (ed.), Beyond Boundaries: Understanding, Translation and Anthropological Discourse, London, Berg, 1993, pp. 210-230.

Ingold, Tim, The Perception of the Environment: Essays in Livelihood, Dwelling and Skill, London, Routledge, 2000.

Joyce, Christopher, and Eric Stover, Witnesses from the Grave: The Stories Bones Tell, New York, Ballantine Books, 1991.

Jelin, Elizabeth, State Repression and the Labors of Memory, Minneapolis, University of Minnesota Press, 2003.

Junquera, Natalia, «Una "fosa común” con 29 cadáveres en la Puerta del Sol», El País, 2010, http://elpais.com/diario/2010/09/03/espana/1283464813_850215.html [consulted May 10, 2021].

Keenan, Thomas, and Eyal Weizman, Mengele's Skull: The Advent of Forensic Aesthetics, Berlin, Sternberg Press, 2012.

Latour and Woolgar, Laboratory Life: The Construction of Scientific Facts, Princeton, Princeton University Press, 1979.

Lave, Jean, and Etienne Wenger, Situated Learning: Legitimate Peripheral Participation, Cambridge, Cambridge University Press, 1991.

Ministerio de la Presidencia, Relaciones con las Cortes y Memoria Democrática (ed.), Memoria Democrática. Fosas y exhumaciones: Las exhumaciones de la Guerra Civil y la dictadura franquista 2000-2019, Madrid, Administración General del Estado, 2020.

Mirzoeff, Nicholas, The Right to Look: A Counter-History of Visuality, Durham, Duke University Press, 2011.

Montero-Gutiérrez, Juan, Paula Alberdi Díez, Sandra Albo Basurto, and Natalia García Redondo, «Aterrados, sacados y (des)enterrados: Una mirada arqueológica a los paisajes del terror caliente de 1936 en Tierras de Castilla», Revista Otarq, 2, 2008, pp. 183-204.

Pinney, Christopher, Camera Indica: The Social Lives of Indian Photographs, Chicago, University of Chicago Press, 1997. 
Renshaw, Layla, «The Forensic Gaze: Reconstituting Bodies and Objects as Evidence», in Zuzanna Dziuban (ed.), Mapping the "Forensic Turn": Engagements with Materialities of Mass Death in Holocaust Studies and Beyond, Vienna, New Academic Press, 2017, pp. 215-236.

Renshaw, Layla, Exhuming Loss: Memory, Materiality, and Mass Graves of the Spanish Civil War. Berkeley, Left Coast Press, 2011.

Resina, Joan Ramón, Disremembering the Dictatorship: The Politics of Memory in the Spanish Transition to Democracy, Amsterdam, Rodopi, 2000.

Rosenblatt, Adam, Digging for the Disappeared: Forensic Science after Atrocity, Redwood City, Stanford University Press, 2015.

Stoler, Ann Laura, Along the Archival Grain: Epistemic Anxieties and Colonial Common Sense, Princeton, Princeton University Press, 2009.

Strassler, Karen, Refracted Visions: Popular Photography and National Modernity in Java, Durham, Duke University Press, 2010.

Taylor, Diana, Disappearing Acts: Spectacles of Gender and Nationalism in Argentina's «Dirty War», Durham, Duke University Press, 1997.

Turrión García, María José, «Documentación generada en las exhumaciones y conservada en el CDMH. Evaluación de la gestión y propuestas», in Ministerio de la Presidencia, Relaciones con las Cortes y Memoria Democrática (ed.), Memoria Democrática. Fosas y exhumaciones: Las exhumaciones de la Guerra Civil y la dictadura franquista 2000-2019, Madrid, Administración General del Estado, 2020, pp. 162-188.

Verdery, Katherine, The Political Lives of Dead Bodies, New York, Columbia University Press, 1999.

Wagner, Sarah, To Know Where He Lies: DNA Technology and the Search for Srebrenica's Missing, Berkeley, University of California Press, 2008.

Wenger, Etienne, Communities of Practice: Learning, Meaning, and Identity, Cambridge, Cambridge University Press, 1998. 
